Vol. 07, No. 01; 2022

ISSN: 2456-8643

\title{
EFFECT OF AZOTOBACTER SP. AND PSEUDOMONAS SP. AS A BIOSTIMULANT IN PETROLLEUM WASTE USING SORGHUM PLANT (Shorgum bicolor L.)
}

\author{
Pujawati Suryatmana*, Rizky Fadillaha, Ardy Berton C L, Nadia Nuraniya Kamaluddin and Mieke Rochimi \\ Setiawati \\ Soil Science and Land Resources Department, Agricultur Faculty ,Universitas Padjadjaran, jl. Raya Bandung- \\ Sumedang Km.21, Jatinangor,West Java, Indonesia \\ https://doi.org/10.35410/IJAEB.2022.5701
}

\begin{abstract}
Inoculation of Azotobacter sp. and Pseudomononas sp. as a biostimulant agent is an appropriate strategy to be carried out to improve the phytoremediation performance of petroleum waste. Azotobacter sp. can produce phytohormones and fix N2, while Pseudomonas sp. are phosphate solubilizing bacteria. The study aims to examine the potential of Azotobacter sp. and Pseudomonas sp. in increasing the biodegradation of petroleum hydrocarbons, in the Phytoremediation system of Sorghum (Sorghum bicolor L.). The research design used was a factorial randomized block design, which consisted of 2 factors, namely the treatment of Azotobacter sp., which consists of 4 levels and treatment of Pseudomonas sp. which consists of 4 levels. The results showed that there was an interaction between Azotobacter sp. and Pseudomonas sp. on the efficiency of hydrocarbon biodegradation, but there was no interaction to the population of Azotobacter sp. and Pseudomonas sp., and growth of sorghum plants. Treatment of 2\% Azotobacter sp. + 3\% Pseudomonas sp. and treatment of 3\% Azotobacter sp. + $3 \%$ Pseudomonas sp showed the value of biodegradation efficiency which tends to be higher than other treatments. Aplication of the two isolates was not able to increase the population of Azotobacter spp, Pseudomonas spp. and the height of sorghum, but can act as a biostimulant to significantly increase the biodegradation process of petroleum hydrocarbons.
\end{abstract}

Keywords: Azotobacter sp., , phytoremediation, petroleum hydrocarbon, Pseudomonas sp, shorgum.

\section{INTRODUCTION}

Petrolleum is a very important energy source until this decade for the industrial and household sectors. The development of the oil industry sector in addition to having a positive impact also has a side effect, namely the occurrence of environmental pollution, is the presence of soil contaminated with petroleum [7], and difficult to decompose which can cause damage to ecosystems and disrupt the water cycle.

Pollutant compounds that enter the environment naturally can be degraded through biological and chemical processes. However, often the burden of pollution in the environment is greater than the rate at which the pollutant degrades naturally. As a result, pollutants will accumulate in the water and soil environment so that human intervention with existing technology is needed to overcome the pollution [11]. One of alternative technology to overcome the environment polluted by petroleum is the phytoremediation technique, which is a technology that is environmentally friendly, effective and economical. The main biological agent in the 
Vol. 07, No. 01; 2022

ISSN: $2456-8643$

phytoremediation method is to utilize plants supported by microbial activity such as bacteria and fungi which aims to remove and improve the condition of soil, sludge, ponds, rivers from contaminants [9].

In this study, the plant selected as a phytoremediation agent was sorghum (Sorghum bicolor L.) combined with the bacterium Azotobacter sp. and Pseudomonas sp. Sorghum plants have features, among others, are more resistant to drought and grow in almost all types of soil, are relatively more adaptable to a wide range of ecological conditions and can adapt to conditions that are not suitable [13], have an extensive root system and spread. so that it can function as a potential phytoremediation agent [17]. However, the use of plants in the phytoremediation process is generally less able to adapt to an environment containing pollutants with high levels of toxicity, so that they can only degrade about less than 5\% of toxic waste [18]. To support the phytoremediation process, it is necessary to add bacterial inoculants as biostimulants that can support the degradation process of petroleum waste and the growth of phytoremediator plants.

Azotobacter sp. is a non-sombiotic bacterium that has the ability to fix nitrogen for supplaying avalaiiblity $\mathrm{N}$ in the soil [10]; [8]. The characteristics of the genus Azotobacter sp. can produce extracellular compounds in high quantities. The characteristics of the resulting extracellular products are diverse in structure and constituent components, and function as biosurfactants [16]. The Azotobacter genus can also excrete biostimulant compounds [4], such as thiamine, riboflavin, pyridoxine, cyanocobalamin, nicotine, indole acetic acid, gibberellins and pantothenic acid [14].

Another bacterium that can have a positive impact on plant growth is Pseudomonas aeruginosa. The ability of P. aeruginosa and to produce Rhamnolipid biosurfactants. Rhamnolipid production is related to the presence of nitrogen which plays a role in biosurfactant synthesis [3] The synergism of the use of the two bacterial inoculants is aimed at improving the performance of the phytoremediation system of soil contaminated with petroleum waste. Potential use of Azotobacter sp. is a producer of $\mathrm{N}$ sources, because this genus is able to fix $\mathrm{N}$ free from the air into $\mathrm{N}$ in a form that can be utilized by other bacteria and plants, while Pseudomonas sp. as bacteria capable of dissolving bound $\mathrm{P}$ into $\mathrm{P}$ that is available to plants [5]. Thus, if the two bacteria are applied in appropriate dose in the phytoremediation system will be able to improve the phytoremediation performance while reducing the use of $\mathrm{N}$ fertilizer and making the use of $\mathrm{P}$ fertilizer more effective.

The purpose of this research is to examine the effect of Azotobacter sp and Pseudmonas sp in improving performance of hydrocarbon biodegradation of waste petroleum in a phytoremediation system using sorghum (Shorgum bicolor L.) plants. An investigation was conducted on the efficiency of hydrocarbon biodegradation, the population of Pseudomonas spp. and Azotobacter spp., and growth of sorghum plants.

\section{MATERIAL AND METHOD}

\subsection{The research design}


The research design used a factorial randomized block design (RBD).

Factor I: treatment of Azotobacter sp. (A)

$\mathrm{a}_{0}=$ without Azotobacter $\mathrm{sp}$.

$\mathrm{a}_{1}=$ Azotobacter sp. $1 \%$

$\mathrm{a}_{2}=$ Azotobacter sp. $2 \%$

$\mathrm{a}_{3}=$ Azotobacter sp. $3 \%$

Factor II: treatment of Pseudomonas sp. (B)

$\mathrm{b} 0=$ without Pseudomonas sp.

$\mathrm{b}_{1}=$ Pseudomonas sp. $1 \%$

$\mathrm{b}_{2}=$ Pseudomonas sp. $2 \%$

$\mathrm{b}_{3}=$ Pseudomonas sp. $3 \%$

\subsection{Initial analysis of experimental soil and production of isolat culture}

Soil samples as much as $500 \mathrm{mg}$ were analyzed for physical and chemical properties of the soil, soil samples were taken compositely at a depth of $0-20 \mathrm{~cm}$ from the soil surface.

Inoculant production of Azotobacter sp. was carried out using liquid mineral media containing $2 \%$ molasses while Pseudomonas sp. using Pikovskaya liquid medium. As much as 10\% pure culture was inoculated into the reactor containing each liquid medium for Azotobacter sp. and Pseudomonas sp. then shaken at $100 \mathrm{rpm}$ for 72 hours at room temperature and pure culture Pseudomonas sp. and Azotobacter sp. harvested.

\subsection{Preparation of Sorghum seed and petroleum contaminated soil}

Sorghum seed preparation and planting Soil for planting media is the order Inceptisols taken compositely. The media used as a growing medium for sorghum was a mixture of Inceptisols mineral soil with compost as basic fertilizer at a dose of $25 \mathrm{~g}$ per $10 \mathrm{~kg} \mathrm{ha}^{-1}$ of soil into each polybag, then incubated for 1 week. The dose of fertilizer used is of the recommended dose of the Ministry of Agriculture for sorghum or cereal crops, namely, $0.5 \mathrm{~g} \mathrm{pot}^{-1}$ urea fertilizer (equivalent to $100 \mathrm{~kg} \mathrm{ha}^{-1}$ ), SP-36 fertilizer $0.25 \mathrm{~g} \mathrm{pot}^{-1}$ (equivalent to $50 \mathrm{~kg} \mathrm{ha}^{-1}$ ), and $0.125 \mathrm{~g}$ pot $^{-1} \mathrm{KCl}$ fertilizer (equivalent to $25 \mathrm{~kg} \mathrm{ha}^{-1}$ ). Urea fertilizer application was given twice during the growing season with a dose of $0.25 \mathrm{~g}$ at the time of planting. planting sorghum and one month after planting as much as $0.25 \mathrm{~g}$.

\subsection{Inoculation of Azotobacter sp. and Pseudomonas sp. and observation research}

The petroleum hydrocarbons used were 5\% TPH (Total Petroleum Hydrocarbon) per $10 \mathrm{~kg}$ of soil media in microcosms which were mixed directly with each treatment of Azotobacter sp., Pseudomonas sp. Then, it is mixed homogeneously and used as a planting medium that already contains compost. Furthermore, sorghum planting and plant maintenance and observations until the final vegetative. Observations were carried out every fourteen days by analyzing the concentration of Total Petroleum Hydrocarbon (TPH), TPH concentration analysis was carried out using the n-hexane gravimetric method. At the end of the study, the calculation of the efficiency of hydrocarbon biodegradation was carried out. Population analysis of Azotobacter sp. and Pseudomonas sp. using the Total Plate Count (TPC) serial dilution method. Observation of 
the growth of sorghum in the vegetative phase was carried out by measuring the increase of plant height every fourteen days from the beginning of planting sorghum seeds until the maximum vegetative phase.

\section{RESULT AND DISCUSSION}

3.1 Characteristics of initial inceptisol of the experiment.

The soil used in this experiment was Inceptisols taken in the topsoil layer with a depth of 0-20 $\mathrm{cm}$ around Ciparanje Jatinangor Land. Results of initial soil analysis represented in Table 1.

Inceptisols in this study had a slightly acidic soil reaction (5.98), low CEC (15.90 cmol kg-1), moderate C-Organic $(2.29 \%)$, low total $\mathrm{N}(0.16 \%)$ and very low potential P2O5. The content of exchangeable cations was low. The inial soil analysis data of Inceptisols has a high dusty clay content compared to sand. This indicates that soils containing higher dusty clay have higher total pores so that the presence of water and air is available in the soil [6] with the acidity level of the soil tends to be acidic.

Table 1. Characteristics of Inceptisols at the beginning of the experiment

\begin{tabular}{|c|c|c|c|c|}
\hline No & Parameters & Unit & value & Criteria*) \\
\hline 1. & $\mathrm{pH} \mathrm{H}_{2} \mathrm{O}(1: 2,5)$ & & 5,98 & slightly acid \\
\hline 2. & $\mathrm{pH} \mathrm{KCl} 1 \mathrm{~N}(1: 2,5)$ & & 5,24 & - \\
\hline 3. & C-Organic & $\%$ & 2,29 & medium \\
\hline 4. & N-total & $\%$ & 0,16 & low \\
\hline 5. & $\mathrm{C} / \mathrm{N}$ rasio & & 14,31 & medium \\
\hline 6. & $\mathrm{P}_{2} \mathrm{O}_{5}$ Bray I & Ppm P & 4,75 & low \\
\hline 7. & $\mathrm{P}_{2} \mathrm{O}_{5} \mathrm{HCl} 25 \%$ & $\mathrm{mg} 100 \mathrm{~g}^{-1}$ & 56,28 & high \\
\hline 8. & $\mathrm{~K}_{2} \mathrm{O} \mathrm{HCl} 25 \%$ & $\mathrm{mg} 100 \mathrm{~g}^{-1}$ & 21,05 & medium \\
\hline \multirow[t]{2}{*}{9.} & Al-dd & $\mathrm{cmol} \mathrm{kg}^{-1}$ & 0,10 & - \\
\hline & H-dd & cmol kg-1 & 0,41 & - \\
\hline 10. & CEC & $\mathrm{cmol} \mathrm{kg}{ }^{-1}$ & 15,90 & low \\
\hline 11. & Texture: & & & \\
\hline 12. & Pasir (\%) & $\%$ & 7 & dusty clay \\
\hline \multirow[t]{2}{*}{13.} & Debu $(\%)$ & $\%$ & 40 & dusty clay \\
\hline & Liat $(\%)$ & $\%$ & 53 & dusty clay \\
\hline
\end{tabular}

3.2 The efficiency level of hydrocarbon biodegradation due to inoculation of Azotobacter sp. and Pseudomonas sp.

The level of hydrocarbon biodegradation due to treatment is shown in table 2., which is represented by the value of biodegradation efficiency describing the phytoremediation performance. 
Vol. 07, No. 01; 2022

ISSN: $2456-8643$

Table 2. Effect of Azotobacter sp. and Pseudomonas sp. in Petroleum Hydrocarbon Phytoremediation Process on Hydrocarbon Biodegradation Efficiency (\%) at week 8.

\begin{tabular}{|ccccc|}
\hline \multirow{2}{*}{ Azotobacter sp. } & \multicolumn{4}{c|}{ Pseudomonas $\mathrm{sp.}$} \\
\cline { 2 - 5 } & $0 \%\left(\mathrm{~b}_{0}\right)$ & $1 \%\left(\mathrm{~b}_{1}\right)$ & $2 \%\left(\mathrm{~b}_{2}\right)$ & $3 \%\left(\mathrm{~b}_{3}\right)$ \\
\hline \multirow{2}{*}{$0 \%\left(\mathrm{a}_{0}\right)$} & $43.71(\mathrm{a})$ & $59.71(\mathrm{~b})$ & $55.41(\mathrm{ab})$ & $51.6(\mathrm{a})$ \\
& $\mathrm{A}$ & $\mathrm{A}$ & $\mathrm{A}$ & $\mathrm{A}$ \\
\hline \multirow{2}{*}{$1 \%\left(\mathrm{a}_{1}\right)$} & $40.80(\mathrm{a})$ & $57.70(\mathrm{~b})$ & $53.76(\mathrm{ab})$ & $53.73(\mathrm{a})$ \\
& $\mathrm{A}$ & $\mathrm{A}$ & $\mathrm{A}$ & $\mathrm{A}$ \\
\hline \multirow{2}{*}{$2 \%\left(\mathrm{a}_{2}\right)$} & $29.68(\mathrm{a})$ & $42.47(\mathrm{ab})$ & $38.98(\mathrm{a})$ & $61.15(\mathrm{a})$ \\
& $\mathrm{A}$ & $\mathrm{A}$ & $\mathrm{A}$ & $\mathrm{B}$ \\
\hline \multirow{2}{*}{$3 \%\left(\mathrm{a}_{3}\right)$} & $42.30(\mathrm{a})$ & $34.65(\mathrm{a})$ & $63.63(\mathrm{~b})$ & $68.58(\mathrm{a})$ \\
& $\mathrm{A}$ & $\mathrm{A}$ & $\mathrm{B}$ & $\mathrm{B}$ \\
\hline
\end{tabular}

Note: Numbers followed by the same letter are not significantly different at the 5\% Duncan test level. Unit of biodegradation efficiency in \%. Letters without brackets are read horizontally and letters in brackets are read vertically ( $<<$ $0.05)$.

The results of the investigation showed that there was an interaction between Azotobacter sp. with Pseudomonas sp. on the level of efficiency of hydrocarbon biodegradation.

Application of 3\% dose of Azotobacter sp. plus 3\% Pseudomonas sp. and 3\% Azotobacter sp. added by $2 \%$ Peudomonas sp. was able significantly $(\mathrm{p}<0.05)$ increasing the efficiency of biodegradation compared to other treatments. However, that two treatments were not significantly different. Treatment of the dose of $2 \%$ Azotobacter sp. added by $3 \%$ Pseudomonas sp. also showed a significant increase $(\mathrm{p}<0.05)$ compared to the $2 \%$ Azotobacter $\mathrm{sp}$. which added $0 \%, 1 \%$ and $2 \%$ Pseudomonas sp. application. The level of biodegradation efficiency in the treatment of 3\% Pseudomonas sp. and 3\% Azotobacter sp. showed the biodegradation value tend highest compared to other treatments.

The results of the investigation showed that the addition of 3\% Azotobacter sp. effectively increase the level of hydrocarbon biodegradation. This is due to that Azotobacter sp. capable of producing extracellular which functions as a biosurfactant. Biosurfactant is an extracellular product of Azotobacter sp. which was able to increase the availability of hydrocarbons as substrates for degrading microorganisms by increasing the emulsification of hydrocarbons, so that they can be readily available as substrates for Pseudomonas sp. As stated by [15] and [16] that Azotobacter chroococum can produce potential biosurfactants to significantly increase the biodegradation of petroleum hydrocarbons. The higher the population of Azotobacter sp. the higher the biosurfactant produced so that the level of solubility of petroleum hydrocarbons is high and easily degraded by petrobacter indigenous or Pseudomonas sp. 


\subsection{The population of Azotobacter spp.}

The population of Azotobacter sp. observed was the final population of Azotobacter sp. at 8 weeks after planting. The result of the final population analysis of Azotobacter sp. (Table 3.) showed that there is no interaction between the application of Azotobacter sp. and Pseudomonas sp. during the phytoremediation process of petroleum hydrocarbons. The result of the investigation of the population of Azotobacter sp. displayed by ranking.

Treatment of Azotobacter sp.1\% added by 3\% Pseudomonas sp. resulted in the density of Azotobacter spp. in soil which tends to be the highest compared to other treatments, although not statistically significant. The growth of Azotobacter spp. in soil based on statistical tests showed that it did not increase significantly due to the availability of substrates for Azotobacter spp. which is limited, this shows that Azotobacter sp. is not able to use hydrocarbons as its substrate. The cell regeneration of Azotobacter spp. process showed slow down, so that there is no significant increase in its growth.

Table 3. Effect of Azotobacter sp. and Pseudomonas sp. to the Final Population of Azotobacter sp. on the Petroleum Hydrocarbon biodegradation process on the $8^{\text {th }}$ week. after planting

\begin{tabular}{|c|c|c|}
\hline No Rank & Treatment & $\begin{array}{c}\text { Azotobacter spp. } \\
\text { dencity } \\
\left(10^{8} \mathrm{CFU} / \mathrm{g}\right)\end{array}$ \\
\hline 1 & $\begin{array}{l}\mathrm{a}_{1} \mathrm{~b}_{3} \text { (Azotobacter sp. } 1 \%+\text { Pseudomonas sp. } \\
3 \%)\end{array}$ & 6.03 \\
\hline 2 & $\begin{array}{l}\mathrm{a}_{0} \mathrm{~b}_{1} \text { (Azotobacter sp. } 0 \%+\text { Pseudomonas sp. } \\
1 \%)\end{array}$ & 5.58 \\
\hline 3 & $\begin{array}{l}\mathrm{a}_{3} \mathrm{~b}_{2}(\text { Azotobacter sp. } 3 \%+\text { Pseudomonas sp. } \\
2 \%)\end{array}$ & 5.28 \\
\hline 4 & $\begin{array}{l}\mathrm{a}_{3} \mathrm{~b}_{0}(\text { Azotobacter sp. } 3 \%+\text { Pseudomonas sp. } \\
0 \%)\end{array}$ & 5.15 \\
\hline 5 & $\begin{array}{l}\mathrm{a}_{1} \mathrm{~b}_{0} \text { (Azotobacter sp. } 1 \%+\text { Pseudomonas sp. } \\
0 \%)\end{array}$ & 4.53 \\
\hline 6 & $\begin{array}{l}\mathrm{a}_{1} \mathrm{~b}_{2} \text { (Azotobacter sp. } 1 \%+\text { Pseudomonas sp. } \\
2 \%)\end{array}$ & 4.41 \\
\hline 7 & $\begin{array}{l}\mathrm{a}_{0} \mathrm{~b}_{0} \text { (Azotobacter sp. } 0 \%+\text { Pseudomonas sp. } \\
0 \%)\end{array}$ & 4.41 \\
\hline 8 & $\begin{array}{l}\mathrm{a}_{1} \mathrm{~b}_{1} \text { (Azotobacter sp. } 1 \%+\text { Pseudomonas sp. } \\
1 \%)\end{array}$ & 4.30 \\
\hline 9 & $\begin{array}{l}\mathrm{a}_{2} \mathrm{~b}_{3} \text { (Azotobacter sp. } 2 \%+\text { Pseudomonas sp. } \\
3) \%\end{array}$ & 4.18 \\
\hline 10 & $\begin{array}{l}\mathrm{a}_{2} \mathrm{~b}_{0} \text { (Azotobacter sp. } 2 \%+\text { Pseudomonas sp. } \\
0 \%)\end{array}$ & 4.18 \\
\hline 11 & $\begin{array}{l}\mathrm{a}_{3} \mathrm{~b}_{0}(\text { Azotobacter sp. } 3 \%+\text { Pseudomonas sp. } \\
0 \%)\end{array}$ & 4.15 \\
\hline 12 & $\mathrm{a}_{2} \mathrm{~b}_{2}$ (Azotobacter sp. $2 \%+$ Pseudomonas sp. & 4.13 \\
\hline
\end{tabular}


Vol. 07, No. 01; 2022

ISSN: $2456-8643$

\begin{tabular}{|c|c|c|}
\hline & $2 \%)$ & \\
\hline 13 & $\begin{array}{l}\mathrm{a}_{0} \mathrm{~b}_{3}(\text { Azotobacter sp. } 0 \%+\text { Pseudomonas sp. } \\
3 \%)\end{array}$ & 4.11 \\
\hline 14 & $\begin{array}{l}\mathrm{a}_{2} \mathrm{~b}_{1}(\text { Azotobacter sp. } 2 \%+\text { Pseudomonas sp. } \\
1 \%)\end{array}$ & 3.51 \\
\hline 15 & $\begin{array}{l}\mathrm{a}_{3} \mathrm{~b}_{1} \text { (Azotobacter sp. 3\% + Pseudomonas sp. } \\
1 \%)\end{array}$ & 3.01 \\
\hline 16 & $\begin{array}{l}\mathrm{a}_{0} \mathrm{~b}_{2}(\text { Azotobacter sp. } 0 \%+\text { Pseudomonas sp. } \\
2 \%)\end{array}$ & 0.07 \\
\hline
\end{tabular}

Based on the concept of hydrocarbon biodegradation, Pseudomonas sp. is including bacteria that can degrade hydrocarbon compounds effectively and is able to produce intermediate compounds that can be used as substrates by Azotobacter sp. and Azotobacter sp. can produce biostimulant compounds and produce $\mathrm{N}$ nutrition. Meanwhile, the result of this study showed that the growth of the Azotobacter spp did not increase, this is assumed that Pseudomonas sp. in this research was not effectively in degrading hydrocarbons circumstance, so that Azotobacter sp could not obtain intermediates substances as its substrates. Also, this might be showing that stimulation of root exudates in the rhizosphere does not always cause encrease contaminant degradation, because it is possible that the rhizosphere microorganism population increases but the degrading hydrocarbon activity by microorganism decreases [2]. A research reported by [19] showed that the presence of petroleum hydrocarbons can reduce the number of bacterial species in a group, although the number of individual species increases with the amount of petroleum waste. Also due to the $\mathrm{pH}$ conditions of the experimental soil which tend to be acidic, resulting the metabolic activity of Azotobacter spp. in the soil was inhibited, leading in the growth of Azotobacater spp. during the hydrocarbon degradation process was not signifficant increasing

\subsection{The population of Pseudomonas sp.}

The results of the investigation of the final population of Pseudomonas sp. shown in Table 4.

The results of statistical analysis showed that there was no interaction between Azotobacter sp. and Pseudomonas sp.application to the final population of Pseudomonas spp. on the phytoremediation system by sorghum plants. Based on the ranking results in Table 4, it can be seen that the treatment $2 \%$ Azotobacter sp. $+0 \%$ Pseudomonas sp. had the highest population value of $20.28 .10^{8} \mathrm{x} \mathrm{cfu} / \mathrm{g}$ compared to other treatments. The addition of Azotobacter $\mathrm{sp}$. and Pseudomonas sp. had no effect in increasing the growth of Pseudomonas spp., this was due to the inhibition caused by complex mechanisms, including the possibility of antagonistic effects caused by Azotobacter sp. to Pseudomonas sp. population. This resulted in the growth rate of Pseudomonas sp. inhibited. Another factor that cause of a low rhizosphere effect phenomenon. The rhizosphere effect of the sorghum plant was not maximal in excreting exudate which acts as a stimulant compound and important nutrients for supporting the growth of Pseudomonas sp. and Azotobacter sp. It can be seen by observations that the sorghum plants showed stunted growth due to the toxicity conditions caused by petroleum hydrocarbons in the soil and resulting the root exudate production process was also to be inhibited. 
Vol. 07, No. 01; 2022

ISSN: $2456-8643$

Table 4. Effect of Azotobacter sp. and Pseudomonas sp. on the Final Population of Pseudomonas spp. on the Petroleum Hydrocarbon Phytoremediation Process on $8^{\text {th }}$ week.

\begin{tabular}{|c|c|c|}
\hline No Rank & Treatment & $\begin{array}{c}\text { Pseudomonas spp } \\
\text { dencity } \\
\left(10^{8} \mathrm{CFU} / \mathrm{g}\right)\end{array}$ \\
\hline 1 & $\begin{array}{l}\mathrm{a}_{2} \mathrm{~b}_{0}(\text { Azotobacter sp. } 2 \%+\text { Pseudomonas } \\
\text { sp. } 0 \%)\end{array}$ & 20.28 \\
\hline 2 & $\begin{array}{l}\mathrm{a}_{3} \mathrm{~b}_{1}(\text { Azotobacter sp. } 3 \%+\text { Pseudomonas } \\
\text { sp. } 1 \%)\end{array}$ & 12.78 \\
\hline 3 & $\begin{array}{l}\mathrm{a}_{0} \mathrm{~b}_{2} \text { (Azotobacter sp. } 0 \%+\text { Pseudomonas } \\
\text { sp. } 2 \%)\end{array}$ & 12.51 \\
\hline 4 & $\begin{array}{l}\mathrm{a}_{1} \mathrm{~b}_{3} \text { (Azotobacter sp. } 1 \%+\text { Pseudomonas } \\
\text { sp. } 3 \% \text { ) }\end{array}$ & 11.58 \\
\hline 5 & $\begin{array}{l}\mathrm{a}_{3} \mathrm{~b}_{2}(\text { Azotobacter sp. } 3 \%+\text { Pseudomonas } \\
\text { sp. } 2 \%)\end{array}$ & 11.33 \\
\hline 6 & $\begin{array}{l}\mathrm{a}_{2} \mathrm{~b}_{2} \text { (Azotobacter sp. } 2 \%+\text { Pseudomonas } \\
\text { sp. } 2 \%)\end{array}$ & 10.10 \\
\hline 7 & $\begin{array}{l}\mathrm{a}_{2} \mathrm{~b}_{1}(\text { Azotobacter sp. } 2 \%+\text { Pseudomonas } \\
\text { sp. } 1 \%)\end{array}$ & 9.61 \\
\hline 8 & $\begin{array}{l}\mathrm{a}_{1} \mathrm{~b}_{0}(\text { Azotobacter sp. } 1 \%+\text { Pseudomonas } \\
\text { sp. } 0 \%)\end{array}$ & 9.45 \\
\hline 9 & $\begin{array}{l}\mathrm{a}_{1} \mathrm{~b}_{1}(\text { Azotobacter sp. } 1 \%+\text { Pseudomonas } \\
\text { sp. } 1 \%)\end{array}$ & 9.23 \\
\hline 10 & $\begin{array}{l}\mathrm{a}_{1} \mathrm{~b}_{2}(\text { Azotobacter sp. } 1 \%+\text { Pseudomonas } \\
\text { sp. } 2 \%)\end{array}$ & 8.31 \\
\hline 11 & $\begin{array}{l}\mathrm{a}_{3} \mathrm{~b}_{3}(\text { Azotobacter sp. } 3 \%+\text { Pseudomonas } \\
\text { sp. } 3 \%)\end{array}$ & 8.21 \\
\hline 12 & $\begin{array}{l}\mathrm{a}_{2} \mathrm{~b}_{3} \text { (Azotobacter sp. } 2 \%+\text { Pseudomonas } \\
\text { sp. } 3 \% \text { ) }\end{array}$ & 8.13 \\
\hline 13 & $\begin{array}{l}\text { a o b } 1 \text { (Azotobacter sp. } 0 \%+\text { Pseudomonas } \\
\text { sp. } 1 \%)\end{array}$ & 7.78 \\
\hline 14 & $\begin{array}{l}\text { a } 3 \mathrm{~b}_{0}(\text { Azotobacter sp. } 3 \%+\text { Pseudomonas } \\
\text { sp. } 0 \%)\end{array}$ & 7.11 \\
\hline 15 & $\begin{array}{l}\text { a } 0 b_{3}(\text { Azotobacter sp. } 0 \%+\text { Pseudomonas } \\
\text { sp. } 3 \%)\end{array}$ & 6.36 \\
\hline 16 & $\begin{array}{l}\mathrm{a}_{0} \mathrm{~b}_{0}(\text { Azotobacter sp. } 0 \%+\text { Pseudomonas } \\
\text { sp. } 0 \%)\end{array}$ & 5.70 \\
\hline
\end{tabular}

Root exudates excreted by plant are alcohol, sugar, and organic acid which can provide sufficient energy and carbon for $10^{8}-10^{9}$ microbial cells per gram of soil in the rhizosphere. The presence of this root exudate causes the microbial population to be 5-100 times increase. Increasing the number of microbial populations is known as the Rhizosphere Effect (ER) [1]. But the results of this study that the exudate produced by the sorghum plant was not able to increase the population 
Vol. 07, No. 01; 2022

ISSN: $2456-8643$

of Pseudomonas sp. as a hydrocarbon-degrading bacterium. As according to the statement of Pivetz et al., [12] that the stimulation of rhizosphere does not always cause the degradation of contaminants increase. It because the rhizosphere microorganisms.

\subsection{Increasing of Sorghum Plant Height}

The plant height observed during 8 WAP represnted on Table 5. The results of statistical analysis showed that there was no interaction between the application of Azotobacter sp. and Pseudomonas sp. on the phytoremediation process of petroleum hydrocarbons on plant height increase.

Table 5. Effect of Azotobacter sp. and Pseudomonas sp. on the increasing of Sorghum Plant Height in the Petroleum Hydrocarbon Phytoremediation Process on the $8^{\text {th }}$ week.

\begin{tabular}{|c|c|c|}
\hline No Rank & Treatment & $\begin{array}{l}\text { Increasig in plant } \\
\text { height }(\mathrm{cm})\end{array}$ \\
\hline 1 & $\begin{array}{l}\mathrm{a}_{0} \mathrm{~b}_{2} \text { (Azotobacter sp. } 0 \%+\text { Pseudomonas sp. } \\
2 \%)\end{array}$ & 7,13 \\
\hline 2 & $\begin{array}{l}\mathrm{a}_{0} \mathrm{~b}_{0} \text { (Azotobacter sp. } 0 \%+\text { Pseudomonas sp. } \\
0 \%)\end{array}$ & 5,73 \\
\hline 3 & $\begin{array}{l}\mathrm{a}_{2} \mathrm{~b}_{2} \text { (Azotobacter sp. } 3 \%+\text { Pseudomonas sp. } \\
1 \%)\end{array}$ & 3,70 \\
\hline 4 & $\begin{array}{l}\mathrm{a}_{1} \mathrm{~b}_{0}(\text { Azotobacter sp. } 1 \%+\text { Pseudomonas sp. } \\
0 \%)\end{array}$ & 2,43 \\
\hline 5 & $\begin{array}{l}\mathrm{a}_{3} \mathrm{~b}_{1} \text { (Azotobacter sp. } 3 \%+\text { Pseudomonas sp. } \\
1 \%)\end{array}$ & 2,20 \\
\hline 6 & $\begin{array}{l}\mathrm{a}_{1} \mathrm{~b}_{3}(\text { Azotobacter sp. } 1 \%+\text { Pseudomonas sp. } \\
3 \%)\end{array}$ & 2,20 \\
\hline 7 & $\begin{array}{l}\mathrm{a}_{2} \mathrm{~b}_{0}(\text { Azotobacter sp. } 2 \%+\text { Pseudomonas sp. } \\
0 \%)\end{array}$ & 2,17 \\
\hline 8 & $\begin{array}{l}\mathrm{a}_{3} \mathrm{~b}_{0}(\text { Azotobacter sp. 3\% + Pseudomonas sp. } \\
0 \%)\end{array}$ & 2,03 \\
\hline 9 & $\begin{array}{l}\mathrm{a}_{1} \mathrm{~b}_{2}(\text { Azotobacter sp. } 1 \%+\text { Pseudomonas sp. } \\
2 \%)\end{array}$ & 1,90 \\
\hline 10 & $\begin{array}{l}\mathrm{a}_{0} \mathrm{~b}_{3} \text { (Azotobacter sp. } 0 \%+\text { Pseudomonas sp. } \\
3 \%)\end{array}$ & 1,87 \\
\hline 11 & $\begin{array}{l}\mathrm{a}_{0} \mathrm{~b}_{1} \text { (Azotobacter sp. } 0 \%+\text { Pseudomonas sp. } \\
1 \%)\end{array}$ & 1,70 \\
\hline 12 & $\begin{array}{l}\mathrm{a}_{3} \mathrm{~b}_{2}(\text { Azotobacter sp. } 3 \%+\text { Pseudomonas sp. } \\
2 \%)\end{array}$ & 1,60 \\
\hline 13 & $\begin{array}{l}\mathrm{a}_{1} \mathrm{~b}_{1} \text { (Azotobacter sp. } 1 \%+\text { Pseudomonas sp. } \\
1 \%)\end{array}$ & 1,27 \\
\hline 14 & $\begin{array}{l}\mathrm{a}_{2} \mathrm{~b}_{1}(\text { Azotobacter sp. } 2 \%+\text { Pseudomonas sp. } \\
1 \%)\end{array}$ & 1,23 \\
\hline
\end{tabular}


Vol. 07, No. 01; 2022

ISSN: 2456-8643

\begin{tabular}{|c|l|c|}
\hline 15 & $\begin{array}{l}\mathrm{a}_{2} \mathrm{~b}_{3} \text { (Azotobacter } \mathrm{sp} .2 \%+\text { Pseudomonas } \mathrm{sp} . \\
3 \%)\end{array}$ & 0,60 \\
\hline 16 & $\begin{array}{l}\mathrm{a}_{3} \mathrm{~b}_{3}(\text { Azotobacter } \mathrm{sp} .3 \%+\text { Pseudomonas } \mathrm{sp} . \\
3 \%)\end{array}$ & 0,50 \\
\hline
\end{tabular}

Application of Azotobacter sp. and Pseudomonas sp. did not increase the plant height of Sorghum significantly, this was because the population of Azotobacter sp and Pseudomonas did not grow optimally on media contaminated with petroleum hydrocarbons, so that the adaptability of Azotobacter sp. and Pseudomonas sp. decreased, which resulted in not providing a significant role as a biological agent that increases the growth of sorghum plants. The plant height in the study was lower than the plant height in the description of plants that grew normally, which was $90 \mathrm{~cm}$. The stunted growth of sorghum plants occurs due to the negative impact of petroleum hydrocarbon contamination, where petroleum hydrocarbon reduced the level of nutrient absorption and water flow by the roots of the sorghum plant. The inhibition of the growth of sorghum plant height was also caused by the $\mathrm{pH}$ of the experimental soil which tended to be acidic.

\section{CONCLUSION}

Application of Pseudomonas sp. 2\% - 3\% added Azotobacter sp 2\% - 3\% can increase the efficiency of hydrocarbon biodegradation significantly in the phytoremediation system using sorghum plant, but both of bacteria were unable increasing the growth of sorghum as a phytoremediator plant. The population density of Azotobacter spp. and Pseudomonas spp. during the hydrocarbon degradation process took place increased but not significant. The $\mathrm{pH}$ conditions which tend to be acidic also suppress the activity and growth of Azotobacter sp. and Pseudomonas sp. Sorghum plants was not able to adapt optimally to toxic stress condition couse of petroleum hydrocarbons existing, by showing stunted growth. Both of bacteria tend to act as biostimulants in the hydrocarbon biodegradation process but do not play a role in increasing the growth of sorghum plants.

\section{Acknowledgments}

The authors acknowledge Universitas Padjadjaran which has funded this research on the implementation of the Research Competency (RKDU) Program, with Contract number: 1959/UN6.3.1/PT.00/2021, and to Manager of Soil Biology Laboratory of Department of Soil Science and Land Resource Management, Agricultural Faculty for supporting, allowing and providing Laboratory facilities.

\section{REFERENCES}

[1]. Atlas, R. M dan R. Bartha. 1998. Microbial Ecology: Fundamentals and Applications. Addison-Wesley Publishing Company. London 1998.

[2]. Bruce E, Pivetz. Ground Water Issue. J. EPA.540 (S-01) : 500, 2001

[3]. Benincasa, M., J. Contiero. M. A Manresa. I.O Moraes. Rhamnolipid production by Pseudomonas aeruginosa LBI growing on soapstock as the sole carbon sourc. Journal of Food Engineering. 54, (4), pp. 283-288, 2002. 
Vol. 07, No. 01; 2022

ISSN: 2456-8643

[4]. Calvo, P., Nelson, L., Kloepper, J. W. Agricultural uses of plant biostimulants. Plant and Soil, 383(1-2), pp. 3-41, 2014.

[5]. Fitriatin, B N., Suryatmana ,P., Yuniarti, A. Istifadah ,N.The Application of Phosphate Solubilizing Microbes Biofertilizer to Increase Soil P and Yield of Maize on Ultisols Jatinangor. ICSAFS Conference Proceedings $2^{\text {nd }}$ InternationalConference on Sustainable Agriculture and Food Security:A Comprehensive Approach, pp. 179-184, 2017. DOI: 10.18502/kls.v2i6.1037

[6]. Hardjowigeno, S. Klasifikasi Tanah dan Pedogenesis. Akademika Pressindo, Jakarta, 2003.

[7]. Haris A. Peranan Mikroba Dalam Mendegradasi Minyak Bumi dan Fenol pada Air Tereproduksi dari Industri Perminyakan (Tesis). Bogor. Program Pasca Sarjana. Institut Pertanian Bogor, 2003.

[8]. Hindersah,R., Nadia Nuraniya Kamaluddin, Suman Samanta, Saon Banerjee, Sarita Sarkar. 2020. Role and perspective of Azotobacter in crops production. Sains Tanah - Journal of Soil Science and Agroclimatology.

17(2), pp. 170-179, 2020

[9]. Melithia,C. L.A. Jhonson, dan W. Amber. Ground Water Polution: In situ Biodegradation Online; http:www.cee.vt.edu / program_areas / enviromental teach / gwprimer /group1 / ind /ex / html, 1996.

[10]. Mengel, K. and A. Kirby. Principle of plant nutrition. International Potash Institute, Switzerland, 1982.

[11]. Nugroho, A. Bioremidiasi Hidrokarbon Minyak Bumi. Bumi Aksara. Jakarta.

[12]. Pivetz, BE. 2001. Ground Water Issue. J. EPA/540/S-01/500. Technology Innovation. Office of Solid Waste and Emergency Response, US EPA, Washington, DC. 36, 2006.

[13]. Rismunandar. Sorghum Tanaman Serbaguna. Sinar Baru. Bandung, 1990.

[14]. Subba Rao, N.S. Mikroorganisme Tanah dan Pertumbuhan Tanaman. Edisi kedua. Jakarta. UI-Press, 1987.

[15]. Suryatmana, P., Kardena, E., Ratnaningsih, E., dan Wisjnuprapto. Biosurfactant characteristic of Azotobacter chroococcum. Journal of MikrobiologyIndonesia. 11, pp. 3034, 2006.

[16]. Suryatmana, P., E. Kardena, E. Ratnaningsih, Wisjnuprapto. Improving the Effectiveness of Crude-Oil Hydrocarbon Biodegradation Employing Azotobacter chroococcum as CoInoculant. Microbiology Indonesia, 1(1), pp. 5-10, 2007.

[17]. Suryatmana, P., Alyani Shabrina., NN Kamaluddin., B.N.Fitriatin.., R. Hidersah., MR, Setiawati. Potensi Tanaman Sorgum (Sorghum bicolor L.), Azotobacter sp. dan Pseudomonas sp. Sebagai agen biologis dalam proses Fitoremediasi Hidrokarbon minyak bumi. SoilRens, 18 (1), pp. 25-33, $2020 .$.

[18]. Truu, M., J. Truu and M. Ivask. Soil Microbiological and Biochemical Properties for Assessing The Effect of Agricultural Management Practices in Estonian Cultivated Soils. Eur. J. Soil Biologi 44, pp. 231-237, 2003.

[19]. Xu, Xingjian,., W. Liu., S. Tian., W.Wang., Q. Qi, P. Jiang., X. Gao, F. Li., H. Li., and H $\mathrm{Yu}$. Petroleum Hydrocarbon-Degrading Bacteria for the Remediation of Oil Pollution Under Aerobic Conditions: A Perspective Analysis ,Front Microbiol. 9, pp. 2885, $2018 .$. 